\title{
A CONTRAJUNÇÃO E O CORPO: O INDIGNO E O ANORMAL
}

\author{
João Carlos Cattelan \\ Universidade Estadual do Oeste do Paraná \\ Cascavel, Paraná, Brasil
}

\begin{abstract}
Resumo: Este estudo se dedica à observação do discurso ordinário (um tipo de discurso que se pauta na ordem discursiva, na reiteração das suas práticas, na trivialidade, na efemeridade e na injunção à manutenção do jogo), fazendo-o a partir de um ponto de vista específico: o foco de análise incide sobre enunciados construídos com conectivos contrajuntivos, em especial com o mas adversativo, buscando elucidar o que eles revelam, por meio da transversalidade discursiva, sobre o interdiscurso que realizam com o imaginário estabelecido; resgatar o dito anterior, produzido antes, em outro lugar e independentemente, que atravessa perpendicularmente o discurso produzido no eixo dêitico do aqui e agora e ter acesso a sustentáculos que comandam as articulações efetuadas entre as partes de um enunciado. Neste trabalho, em especial, buscar-se-á observar como enunciados contrajuntivos opõem partes de enunciado, quando a temática se refere à corporalidade física do homem.
\end{abstract}

Palavras-chave: Discurso Ordinário. Transversalidade. Contrajunção. Corporalidade.

Se não é mais ao corpo que se dirige a punição, em suas formas mais duras, sobre o que, então, se exerce? A resposta dos teóricos é simples, quase evidente. Dir-se-ia inscrita na própria indagação. Pois não é mais o corpo, é a alma. À expiação que tripudia sobre o corpo deve suceder um castigo que atue, profundamente, sobre o coração, o intelecto, a vontade, as disposições. (FOUCAULT, 1999, p. 18).

\footnotetext{
* Doutor em Linguística (UNESP/Araraquara - SP). E-mail: cattelan@unioeste.br.
} 


\section{INTRODUÇÃO}

Os enunciados com operadores contrajuntivos ${ }^{1}$ possuem dois blocos de sentido: um é o tema e outro a negação da conclusão, se não houvesse a contradição. Um enunciado contrajuntivo encadeia as partes A e B de um enunciado, destinando-se uma delas a negar a conclusão que a outra torna possível. Busca-se, pois, elucidar o que permite as conclusões de A, negadas por B.

Frente à contrajunção, dada a parte A do dito e o suporte em crenças, o interlocutor pode fazer inferências que, se não forem negadas, são possíveis. Sendo dito A e havendo noções comuns, ele pode concluir B, pois o encadeamento sobre $\mathrm{C}$, à sombra, como evocação lateral, indica conclusões possíveis. Entretanto, na contrajunção, dito A, há uma conclusão que não pode ocupar o espaço de $\mathrm{B}$, pois não é válida, embora uma "verdade" seja ratificada. No limite, a parte encabeçada pelo contrajuntivo cria uma ressalva tênue frente a uma crença dogmática.

\section{O DISCURSO ORDINÁRIO: UM ESTUDO [DO] TRIVIAL}

Tem-se, assim, o ângulo pelo qual o objeto de estudo (corpo) será focado. Além disso, este estudo se origina de uma pesquisa que toma o Discurso Ordinário como tema. Para a sua definição, um apoio vem da distinção feita por Maingueneau (2008) entre tipos de discurso, "relacionados a certos setores de atividades da sociedade: discurso administrativo, publicitário, político etc., com as subdivisões que quisermos" (p. 16-17), e gêneros do discurso (grifos do autor), "entendidos como dispositivos sócio-históricos de comunicação, como instituições de palavras socialmente reconhecidas" (p. 17). Para o autor, "tipos e gêneros são tomados em uma relação de reciprocidade" e "a noção de tipo de discurso é heterogênea, trata-se de um princípio de agrupamento de gêneros

\footnotetext{
${ }^{1}$ A noção de operadores contrajuntivos situa, quase que obrigatoriamente, a reflexão no terreno da Pragmática. No entanto, aqui, apesar do recurso a esta categorização, não se quer colocar a discussão neste lugar, mas no da Análise de Discurso (em sentido amplo), pois se entende que o locutor pertence a uma conjuntura social e histórica, é clivado pelo inconsciente e é afetado por formações discursivas que o antecedem.
} 
que pode corresponder a duas lógicas diferentes: a do co-pertencimento a um aparelho institucional e a da dependência de um mesmo posicionamento" (p.17, grifos do autor), mas a distinção ajuda a situar este tipo discursivo.

Quanto aos tipos de discurso, o autor os relaciona a setores de atividades da sociedade, o que os localiza numa esfera envolta por compromissos e cria tipificações limitadoras: o discurso jurídico, o publicitário, o econômico e o pedagógico, relacionando-os à atividade social que os produz, faz circular e os legitima: o copertencimento, aqui, refere-se a uma instituição. Isso não ocorre com o discurso ordinário, pois não tem uma instituição que o ancore, já que se serve de todas e as faz suporte, rompendo sua rigidez monolítica, usando-as por um tempo e as deixando a seguir. A sua unidade não vem de um suporte institucional, mas do seu uso, à revelia de autorização. O discurso ordinário não é jurídico, religioso ou político, mas está entremeado aos corpora que emanam deles. Ele aparece na voz do padre, sem ser religioso; na do juiz, sem ser jurídico; na do candidato, sem ser político. Mas, apesar de camaleônico, pode ser encontrado, também, nas conversas informais e nos diálogos efêmeros.

O discurso ordinário também não possui um posicionamento, como o discurso socialista, neoliberal, católico ou médico. Ele se alimenta de vários, pois reafirma enunciados sobre temas, juízos e valores. A unidade do discurso ordinário vem da ordem a que pertence e da sua contribuição para reforçá-la. O discurso ordinário não se baseia num aparelho institucional ou num posicionamento, mas transita pelas instituições, usando-as. Sua sobrevivência é parasitária e usa posicionamentos múltiplos; às vezes: paradoxais. Sua unidade vem da ordem que o habita e que impede a ruptura das malhas.

Se o que constitui um tipo discursivo é o fato de pertencer a uma atividade social, o discurso ordinário não seria um tipo. A sua unidade não provém de instituição social, mas da atitude renitente de manutenção de posicionamentos. Embora pertença à atividade social, não está circunscrito a uma. Ele habita esferas diferentes, indica crenças de paragens distintas e se mescla aos discursos canônicos. Ele tira seu sustento das esferas existentes. 
A unidade do discurso ordinário (como concebido aqui) vem da ratificação das crenças do imaginário ${ }^{2}$ : das verdades, desejos, sonhos, medos e tentações que perduram para além do gesto fundador. Ele atualiza vozes cuja autoria se perdeu. Insidiosas, elas fazem valer o que afirmam, criando um hiato entre o que é e o que dizem ser. Ele reitera a ordem, reafirma o "imutável", impõe o "desejável" e instila "crenças".

O discurso ordinário se vale de uma profusão de dispositivos sóciohistóricos e de palavras socialmente reconhecidas. Ele se acha no anúncio que ratifica um valor social; no aviso que reafirma uma crença sobre a higiene; no turno de fala que reitera a obrigação do professor de cumprir o horário; na afirmação da criança que impõe que a mãe atenda a uma obrigação; nas "sentenças" na parede da igreja dizendo como a criança deve se comportar; na conversa de bar em que o que é ser homem é reafirmado; na propaganda em que a imagem de mulher é confirmada; na carta em que o modo de ser filho é estipulado. Os gêneros utilizados podem ser qualquer um, pois ele não tem pudor de fazer uso de gêneros “impróprios" para validar a ordem estatuída.

Mas, há um lugar peculiar para que seja observado: a réplica curta do diálogo cotidiano ${ }^{3}$. Ele se imiscui em suas entranhas e faz com que posicionamentos pareçam peculiares e deneguem a força anímica e o imaginário que o assombram. Ele se abastece da ordem e da injunção e as cadeias, às vezes, não estão ajustadas para impedir que penetre por suas frestas. O discurso ordinário não tem território, por não ter uma unidade que o renda ou espaço prévio que o circunde. Ele se revela pelo uso de espaços, tempos e lugares diversos. Ele é o discurso da "lei", da "norma" e da "prescrição".

\footnotetext{
${ }^{2}$ Apesar de os conceitos de imaginário e ideologia poderem (e deverem) ser tidos como distintos, a aproximação entre eles não parece algo inusitado ou inconciliável, já que o primeiro, conforme Castoriadis (1982), é o responsável pela criação da segunda. Dito de outro modo: tudo que é ideológico tem uma origem calcada no imaginário, mas nem tudo que pertence ao imaginário é necessariamente ideológico: é uma questão de escopo e primazia. Em face da delonga que a discussão traria, dá-se o tema como estabelecido.

${ }^{3}$ Esta réplica ocorre em interações face a face, mas também em reproduções de nível secundário. Mas, substancialmente, elas não são distintas, embora se deva reconhecer, é óbvio, que, no segundo caso, há uma enunciação sobre a enunciação, uma voz sendo sobredeterminada por outra, enquanto, no primeiro, a enunciação é oriunda de primeira instância.
} 
Parece mais adequado considerar o discurso ordinário como o princípio de fixação do pensável, dizível e "sensível". A unidade que o constitui conjuga trivialidade e injunção, efemeridade e tradição, fugacidade e memória, evanescência e durabilidade: a sua força vem de outro lugar; se aparece, traz à memória um modo de ser aceito e praticado: às vezes, pranteado.

Cabe considerar, ainda, a lição de Maingueneau (2008) de que a unidade hipotetizada impõe apresentar "hipóteses de trabalho argumentadas" para justificar a associação de "diversos conjuntos discursivos em uma mesma configuração sem, porém, reduzir sua heteronímia" (p. 20), as quais se busca delinear, para ter um parâmetro de concepção que selecione o que pertence ao (des)território constituído. Se um enunciado como nossa cozinha está à sua disposição para uma visita pode ser reunido a outro como ela é mulher, mas é competente, ou a outro como eu não tenho dó. Eu falei, minha mãe falou, até a psicóloga falou ou a outro, ainda, como o pote de mel quebrou, isto é possível, pois as suas características são a trivialidade e a efemeridade que agem de modo imperativo e indiciam a aceitação e a punibilidade da transgressão.

É do discurso ordinário o que pertence à ordem do discurso, contribui para ratificá-la, ocorre em situações triviais ${ }^{4}$, pouco se vale de pompa ritual e faz o jogo definido. Ele dita o que deve ser pensado, dito e sentido: atende à ordem; sedimenta crenças e valores; ratifica o imaginário; é efêmero, trivial e corriqueiro: um sopro que simula apatia; nega sua importância: sua efemeridade revela sua durabilidade; e, por fim, atende à estagnação.

\section{CIRCUNSCRIÇÃO DA MOTIVAÇÃO DO ESTUDO}

Vê-se, pois, que o discurso ordinário é escapadiço, pois não é um tipo pautado numa instituição ou posicionamento. Deseja-se ter mostrado que a sua unidade advém do compromisso com o imaginário e com a efemeridade. Objeto de contornos instáveis, ele pode ser concebido como um sistema de dispersão que aborda temas infindos e, ao fazê-lo, revela o solo que o alimenta.

\footnotetext{
${ }^{4}$ De primeiro ou de segundo nível: produzidas ou reproduzidas.
} 
$\mathrm{O}$ discurso ordinário revela que o que o sustenta se encontra no terreno do pressuposto, interdito ou não sabido e, se não for abordado, continuará pertencendo ao terreno do desconhecido e não combatido. Ignorar o que ancora os enunciados é "ignorar a eficácia material do imaginário" (PÊCHEUX, 1995, p. 119). Os alicerces da enunciação que criam o dizível são valores, crenças, concepções e um solo de partilha que revela a "cumplicidade entre o locutor e aquele a quem ele se dirige, como condição de existência de um sentido" (p. 114, grifo do autor).

As citações de Pêcheux mostram as razões para o discurso ordinário ser estudado. A primeira se refere ao fato de que o imaginário, às vezes, ligado à imaginação criativa, deveria ser concebido como regulador da atividade social. As atitudes que se devem ter, com as suas sanções, mais do que resultado de conhecimento racional, que revela o mundo em transparência, resultam da autoinstituição imaginária da sociedade, que, tendo alcançado uma fase de cristalização, denega a historicidade que a constitui. Criando efeitos de naturalização e de ontologização, o imaginário anula a sua força motriz e pretende que o movimento típico seja a estagnação: é esse paradoxo que o torna eficaz.

A segunda remete à questão de que a desistoricização demanda "uma espécie de cumplicidade" entre os interlocutores e pede a pressuposição de um solo de valores, mesmo que ele ocorra no terreno da inconsciência; talvez, por isso, o imaginário tenha a eficácia esclerosadora que possui. Age-se como se, embora não se saiba de onde vêm conceitos e noções, tomando por natural o costume: "conduta inercial, habitual e induzida" (THOMPSON, 1998, p. 14). Para o autor, as rodas do costume regulam os homens, levando-os a "fazer o que sempre fizeram". Para isto, é preciso que os locutores, sem saber, partilhem um imaginário e contribuam para que ele dite o que pensar.

O discurso ordinário revela fragmentos do imaginário. Nele, trivial, corriqueiro, espontâneo, "oral" e simples, o solo que o sustenta pode ser detectado. Nele, encontram-se traços "de um inconsciente ao mesmo tempo coletivo e individual, traço incorporado de uma história coletiva e de uma história individual que impõe a todos os agentes, homens e mulheres, seu sistema de pressupostos imperativos" (BOURDIEU, 1999, p. 70). Um 
enunciado se ancora num conjunto de pressupostos, mas eles ocorrem em silêncio, pois, já que estão "acordados", não precisam ser enunciados: participam do "conhecimento". Concorda-se que é assim porque sempre foi assim.

O estudo do discurso ordinário revela bases imaginárias do dizível, que, para Castoriadis (1982, p. 154), em face do sentido corrente, é 'alguma coisa 'inventada' - quer se trate de uma alguma coisa 'inventada' - quer se trate de uma invenção 'absoluta' [...] ou de um deslizamento, de um deslocamento de sentido". Para ele, os locutores se pautam no imaginário, que produz a alienação, ou seja, "a autonomização e a dominância do momento imaginário [...] (frente) à sociedade” (p. 159). O discurso ordinário revela traços desses processos discursivos e, no fim, permite que se ache "o passado vivido como presente, os fantasmas mais poderosos do que os homens de carne e osso" (p. 160).

A razão para o discurso ordinário ser objeto de estudo se deve ao fato de se alicerçar num imaginário limitador, que impõe as condições do discurso e do silêncio, sendo preciso interrogá-lo sobre suas condições, para que o não dito seja desencavado. Há um modo de o imaginário que impõe o discurso ser combatido: apreender os princípios que ratifica e confirma nos enunciados triviais. Trata-se de tirar-lhe a autonomia, revelar suas invenções, interrogá-lo sobre sua força, amenizar sua eficácia, revelar a cumplicidade em que se ancora; trata-se de desarmá-lo, fazendo com que os mortos deixem de se apoderar dos vivos.

\section{IMAGINÁRIO EM RÉPLICAS DE RELAÇÕES DIALÓGICAS}

Para Barthes (2000, p. 46), "meu corpo é bem mais velho do que eu, como se conservássemos sempre a idade dos medos sociais com os quais o acaso da vida nos pôs em contato"; para Bourdieu (1998, p. 38, grifos do autor), "tudo leva a crer que as instruções mais determinantes para a construção do habitus se transmitem sem passar pela linguagem e pela consciência, através de sugestões inscritas nos aspectos aparentemente mais insignificantes das coisas" e "as práticas da existência comum são carregadas de injunções tão poderosas e tão difíceis de revogar por serem 
silenciosas e insidiosas, insistentes e insinuantes". Assim, nas réplicas curtas de relações dialógicas, anacronismos se imiscuem, revelando os enunciadores que ancoram o locutor. Nos enunciados curtos do cotidiano, de modo transversal, estão vozes que atravessam os séculos.

Este estudo analisa réplicas curtas de relações dialógicas e busca apreender o que afeta os sujeitos", fazendo-os dizer o que dizem. Entendese, com Thompson (1998, p. 14), que "Os homens professam, protestam, comprometem-se, pronunciam grandes palavras, para depois fazerem o que sempre fizeram. Como se fossem imagens mortas, instrumentos movidos exclusivamente pelas rodas do costume". Um exemplo é o enunciado de um senhor que, ao apresentar um vizinho ao outro, o fez afirmando "Este é o João: ele é professor, mas é um cara legal". Grosso modo, ele produziu dois enunciados, unidos pelo mas. Há, porém, outro enunciado (professores não são legais) que aceita a contrajunção; sem ele, o discurso não seria proferido.

Este enunciado ajuda a ilustrar o discurso ordinário, o gênero réplica curta de relações dialógicas e o estudo que se pretende realizar: desvendar parte do solo imaginário que ancora os discursos. Ele permite afirmar que este solo imaginário perpassa os discursos, sem o locutor ter dele consciência, pois, quando o professor indagou o que o outro pensava dos professores, a resposta foi: "são necessários para que a população tenha educação". Contradição, falha de raciocínio, ingenuidade? A lacuna vem do descompasso entre o que se sabe que se sabe e o que não se sabe que se sabe, mas que, embora não se saiba, atua sobre o discurso.

Pensa-se que esse estudo se justifique, porque contribui para perceber crenças que se tem sem saber que se é constituído por elas. Não se pretende a desalienação, pois "o fato de conhecer-se como tal não o faz [o homem] sair de seu modo de ser, como dimensão do fazer social-histórico. Mas pode permitir-lhe ser lúcido a respeito de si mesmo. O que denomino elucidação é o trabalho pelo qual os homens tentam pensar o que fazem e saber o que pensam" (CASTORIADIS, 1982, p. 14). O que se busca é a elucidação de aspectos do imaginário que sustenta a sociedade, a percepção de por que se pactua com eles e a quem tal conivência beneficia. 
A aposta é que se pode dar conta dos valores que se professam e optar por mantê-los, mas, se as atitudes se pautarem neste grau de percepção, ter-se-á algo de autonomia. Trazer à luz princípios discursivos contribui para que o homem se torne mais lúcido, no sentido de saber o que lhe foi dito. "Nada é sagrado; tudo pode ser dito" é o título de um livro de Vaneigem (2004), o que não significa que, tendo sido dito, deva ser aceito; a premissa é a de que tudo deve ser dito para ser combatido.

Há, pois, um tipo discursivo que implica, para Bakhtin (1992, p. 279), "uma esfera da atividade humana relativamente estabilizada", com organização, temática e composição mais ou menos fixa. Pode-se supor que ele remete às interações face a face, em primeiro ou segundo grau. Outra hipótese se refere a o discurso ordinário ter um solo comum de crenças para que o silêncio se transforme em profusão de enunciados. Outra, ainda, refere-se ao fato de afirmar que, entre a materialidade do texto, o jogo dos significantes, a estrutura resultante e o imaginário cultural, há uma relação intrínseca e constitutiva.

Mas a hipótese maior a ser considerada é que, nas atividades verbais cotidianas, podem ser percebidas crenças que orientam os discursos sem os envolvidos perceberem e, se não se percebe o imaginário que dita o que se deve dizer, o discurso continuará pautado no que julga a verdade e a forma adequada de enfocar o mundo. Os enunciados ordinários revelam as crenças que os sustentam.

Manipulação, mistificação, mitificação, estereótipo, arquétipo, ilusão, falsa crença, ideologia, representação e conspiração são termos que a linguagem cotidiana usa para o fenômeno. Cada um aponta para um descompasso entre o que se diz ser e o que é. Não é neste prisma que se pretende se colocar, já que estes conceitos supõem uma verdade ao fundo, como se o locutor soubesse o que é e o que se espera que seja, vivendo papéis que não se relacionam ao seu "verdadeiro" eu. Pretende-se perceber que forças the permitem sair do silêncio. Trata-se de estudar o discurso ordinário por meio de "réplicas curtas de relações dialógicas", sob a ótica da Análise de Discurso, e compreendê-lo quanto à sua sustentação imaginária, já que o homem não se iça do pântano pelos próprios cabelos. 
Os enunciados, ouvidos no que apagam porque tomam como evidente, permitem desencravar crenças que produzem compreensões e negam a atividade que as gerou. Pode-se trazê-las à tona por meio da análise dos dizeres das ruas, dos bares e dos lares; dos enunciados que se proferem sobre os corpos, o tempo e o espaço; dos escritos que se encontram em placas, banners...

\section{SOBRE A NATUREZA CONTRASSILOGÍSTICA DO CONTRAJUNTIVO}

Em Semiologia Literária, no Colégio de França, Barthes fez uma afirmação programática que permite um projeto maciço de pesquisa. $\mathrm{O}$ francês (1997, p. 14) dizia: "a língua como desempenho de toda linguagem, não é nem reacionária, nem progressista; ela é simplesmente: fascista; pois o fascismo não é impedir de dizer, é obrigar a dizer". A tese, levada à radicalidade na Aula, alerta que os recursos da língua se explicam à luz dos grupos sociais e das suas concepções culturais.

Para ele, deve-se orientar o olhar para a maneira de produzir os enunciados, pois o modo produz efeitos de sentido. Poder-se-ia, assim, ter uma diretriz para um programa de pesquisa: por que se diz o que se diz do modo que se diz? Tem-se, por meio da atividade, acesso à "cultura" de um grupo social. É o que se objetiva aqui, em relação ao uso do mas, quando ele articula enunciados. Neste estudo, observa-se esse operador sob a ótica discursiva, analisando-o quanto ao fato de unir enunciados contraditórios (que contradição é essa, já que os enunciados não parecem contraditórios?) e à possibilidade de perceber se o seu uso permite acesso à parte de um imaginário cultural.

Um lugar que denuncia que a civilização ocidental é clássica e, logo, lógica e (pretensamente) racional reside no funcionamento dos operadores argumentativos. É possível perceber o silogismo que os sustenta, mesmo que a articulação crie conexões de outra natureza. Seja por meio do idealismo platônico ou do empirismo aristotélico, os raciocínios revelam uma atitude "racional" que, às vezes, não partilha da natureza "conceitual" que aparenta ter. Os preconceitos, as fofocas, os chistes e as gafes mostram a busca da submissão do mundo a uma ordem canônica. É o que ocorre 
com os adversativos: a ressalva que fazem se pauta num silogismo implícito que evidencia um caso sobre o qual a regra não se aplica, ratificando-a para os outros casos.

A contrajunção possui um princípio imaginário que faz com que, afirmando A e sabendo $\mathrm{C}$, o locutor profira $\mathrm{B}$, para impedir que $\mathrm{o}$ interlocutor, partícipe da comunidade, aplique o silogismo canônico, evitando deduções que faria em outras situações. Uma reflexão contrajuntiva se ancora num encadeamento silogístico, evitando que, num caso, a norma social seja aplicada.

As partes de enunciados com operadores contrajuntivos não invalidam regras gerais, mas as tornam ainda mais rígidas. Elas indiciam que, num caso, a implicação "dedutiva" não deve ser feita, pois não se aplica ao caso excedente. Os contrajuntivos têm uma natureza contrassilogística, já que o silogismo que os ancora deve ser negado em, pelo menos, um caso. Isto revela um perfil paradoxal da contrajunção, já que, enquanto nega a aplicação da norma, ela a ratifica em bem maior extensão.

Os enunciados contrajuntivos, dada a sua natureza paradoxal, explicitam por que um caso contrassilogístico não ratifica um silogismo normalizado. Observando em que um adversativo vai contra a crença geral, acede-se a um princípio do imaginário. Aqui, pretende-se fazê-lo sobre como a corporalidade é percebida: e exigida: este é objetivo específico e geral deste estudo.

\section{A CONTRAJUNÇÃO E O CORPO ANORMAL}

Como os enunciados não definem o corpo normal (afirma-se o que ele não deve ser apenas), mas se referem aos equívocos da corporalidade indigna, o foco recairá sobre os preceitos que se referem ao corpo indesejável, não sancionado pela coletividade.

Este estudo observa o discurso ordinário, que atende à ordem discursiva, reitera práticas, é trivial, é efêmero e coopera com a injunção à manutenção do jogo, fazendo-o sobre enunciados contrajuntivos, em especial, com o mas adversativo, buscando elucidar o que mostram sobre o 
interdiscurso com o imaginário, resgatar o saber que atravessa o discurso e ter acesso a suportes que organizam as articulações. Em especial, observarse-á como enunciados contrajuntivos opõem partes de enunciado sobre o corpo. Os enunciados provêm de fontes heterogêneas e o seu liame se dá pela pertença ao discurso ordinário e ao tema em foco. Eles são "ordinários" por atenderem aos requisitos e não por chegarem ao interlocutor direta ou indiretamente.

(A) Num episódio da série Two and a Half Man, Alan discute com o irmão, Charlie, sobre como deve agir com a namorada, já que pretende terminar o romance. Durante o diálogo, ocorreu a troca de turnos transcrita a seguir:

(1) - Ela tem alguma foto comprometedora?

- Há uma em que estou nu, mas de capa e máscara.

Alan se refere à nudez corporal que seria um problema (uma foto comprometedora), caso viesse a ser pública e fosse relacionada ao portador do corpo nu, o que indica que a nudez pode existir em espaços fechados, mas não pode ser revelada, sob pena de comprometer quem a mostra por “atentado violento ao pudor". Ratificando o princípio de que a nudez é penalizável (talvez por isso quem posa nu para revistas denomina essa atividade $n u$ artístico), Alan revela que, na foto, ele veste uma máscara, o que evitaria o problema, pois não seria relacionado à nudez exibida.

Alan ratifica o preceito de que, em público, o corpo deve estar coberto (ditame vivido de modo radical por islâmicos) e não pode ser objeto de apreciação, estranhamento ou escândalo: pudor. A falta de ocultação do que é íntimo se instala na zona do impuro, do imoral e do pecaminoso, uma vez que toda forma de nudez remete à sensualidade, ao erotismo e à sexualidade: tema de tabus e preconceitos.

(B) Na revista Caras, número 14, ano 16, edição 804, de 3 de abril de 2009, Nathalia Timberg, falando sobre a vida de artista e as opções que essa escolha profissional teria imposto, disse:

(2) Nunca quis ter filhos. Foi uma escolha minha. Mas tenho uma família unida e amigos. 
O foco incide sobre a obrigação de a mulher ser mãe e não poder deixar de cumprir a "vocação" para a maternidade. A atriz indica uma opção inaceitável, que a opção natural seria ter filhos e que não deveria ter uma família unida e amigos, pois essas são sanções aplicáveis à mulher que opta pela não maternidade.

O amparo de crenças dita que deveria, por ser mulher, ter filhos e não o contrário. É este suporte que permite as relações que ela realiza, fazendo-o como forma de poder negar que a implicação "lógica" valha para si, pois, ao contrário de outras que optaram por não ter filhos, ela tem uma família estruturada e amigos.

Dado o modo como a locutora encadeia o enunciado, pode-se afirmar que o preceito social sobre a mulher ter a obrigação de ser mãe é ratificado, não se aplicando ao seu caso, o que justifica o contrajuntivo. A mulher, cuja opção foi oposta, parece ser portadora de uma incompletude que se deve ao fato de indicar alguma rebeldia, com isso, deixando de gozar dos "benefícios" que as bem comportadas recebem como prêmio.

(C.1) No corredor de uma universidade, em 17 de julho de 2008, durante a troca de turnos de dois docentes, dentre outras coisas faladas, o foco de atenção incidiu sobre o novo estagiário. Parte do diálogo ocorrido aparece transcrita a seguir:

(3) - A estagiária Priscila saiu. Entrou um moço no lugar dela.

- Eu vi!

- Você viu que ele é estrábico?

- Mas parece bem gente boa: ele é bem solícito.

Neste caso, o tema se refere a uma questão física, traços que o corpo apresenta sem que o portador os tenha escolhido. $O$ estrabismo do estagiário é congênito, o que não o desculpa, pois se aplica uma sanção sobre o defeito físico. A contrajunção se justifica, na medida em que o diálogo toma a anormalidade física como problema que teria consequências sobre as atitudes e os comportamentos: como se, entre questões de ordem física e moral, houvesse uma relação lógica. 
O encadeamento silogístico pode ser explicitado como segue: o preceito geral de crença é pessoas estrábicas não são gente boa e nem são solícitas. O estagiário apresenta estrabismo. Ele seria, pois, uma pessoa antipática. Mas o silogismo é contradito, pois o estagiário foge às expectativas sobre pessoas que têm um defeito físico.

Percebe-se como, amparando o locutor, existe um princípio de crença: perfeccionista (seria um exagero chamá-lo de nazista?) que exige que os corpos sejam perfeitos. Como "os olhos são os espelhos da alma" e "quem que não sustenta o olhar do outro é falso", parece justo inserir o estagiário no caso das pessoas que não têm uma relação interpessoal agradável.

(C.2) O diálogo a seguir ocorre entre Leda e Alceo, no filme The Stones Merchant, à 1:26'00. A discussão incide sobre Leda ser amante de Numiat Ulah, envolvido com o fundamentalismo e, em tese, ser um terrorista e suicida. Alceo foi vítima de uma mina e perdeu as pernas, ficando aleijado.

(4) - Leda, olhe para mim, olhe para mim, por favor. Sou só meio homem. Você está fugindo com um terrorista. O mercador está envolvido com a $\mathrm{Al}$ Qaeda. Mas não posso impedir uma mulher linda como você de fugir com outro homem.

- Não é verdade. Só diz isso porque está com ciúme e porque não sabe lidar com a situação.

A impossibilidade de evitar que Leda fuja com Vicedomini (sobrenome italiano e original de Numiat Ulah) se deve a Alceo ser só meio homem e não poder impedi-la de fugir com um terrorista que está envolvido com a Al Qaeda. A relação entre estes encadeamentos revela a resignação frente à imperfeição física. A impotência adviria da condição física que o faria renunciar à mulher, por não ter a força necessária para retê-la nem a beleza física que poderia impedir uma mulher linda como [ela] de fugir com outro homem. Alceo possui duas limitações para ser marido e homem: tem um corpo mutilado sem beleza.

A oposição contrajuntiva se torna plausível, quando se percebe que considera a fuga da normalidade física uma deficiência que impede o 
homem de reter a esposa, por não possuir o padrão de beleza "desejável”. A imperfeição física impediria atividades que demandam força e impediria a realização afetiva.

A relação contrajuntiva de Alceo é uma entoação de resignação que condescende com a norma. Ele assume uma impotência que deriva da sua condição física e que está atrelada às duas rupturas em relação à "normalidade". Se homens pela metade e feios não podem ter prazeres, é previsível a aceitação passiva de Alceo.

(C.3) Em 3 de agosto de 2009, às 22’15, no canal 32 da Warner Bros, em The Mentalist, enquanto se investigava a morte de um homem carbonizado, a mulher, à entrada de Thommy, que tinha problemas psíquicos, proferiu o seguinte enunciado:

(5) - Ele é deficiente, mas muito independente, graças a Deus.

Neste caso, aborda-se a deficiência psicológica ou cognitiva. Thommy, que finge querer um pedaço de bolo, é o assassino que simula ser deficiente, ter distúrbios de maturidade e receber tratamento distintivo, dada a suposta debilidade que o marginaliza e o põe sob cuidados especiais.

Como se percebe, o enunciado não dá um nome ao problema: Thommy é deficiente. Assume-se que a insuficiência é um problema que repercute sobre o caráter. Pela falta de nome técnico, o locutor se refere a toda e qualquer imperfeição que remeta a alguma insuficiência frente ao padrão humano normal e espera que todos atendam ao que esse padrão estabelece. Que o portador escolhesse atender ao padrão não importa, quando se trata de discriminar quem não se encaixa.

A deficiência de Thommy é a causa para ser dependente e a aplicação do silogismo o coloca como precisando de tratamento, menosprezando-se as possibilidades, se a relação se baseasse na confiança. O discurso revela a arrogância da normalidade, que impõe a expectativa do mundo. No episódio, o rapaz simula ser deficiente, para tramar assassinatos para vingar um amigo.

Seja pelo isolamento dos que são imperfeitos fisicamente ou daqueles que portam alguma forma de insuficiência psicológica, o mundo 
da normalidade fixa limites entre quem pode viver em paz (em silêncio), embora sob vigilância constante, e aqueles que devem ser regulados, discriminados, distinguidos, controlados e alertados sobre a fuga à ordem. Narcisismo (e nazismo) é o que conduz as apreciações valorativas, impondo que tudo se faça à imagem do mesmo, para evitar a ameaça que a diferença representa para a fraternidade convencional.

(D) $\mathrm{O}$ enunciado a seguir ocorreu num almoço familiar, em 3 de fevereiro de 2008, quando alguém falava sobre a viagem. Passando por Santa Catarina, ele teria visitado um parente seu.

(6) - Eu não vim direto. Parei em Chapecó. Tenho uma tia lá. É a única tia que eu ainda tenho. Ela tem noventa e um anos, tá véia, mas tá firme na parada!

O foco incide sobre a longevidade do corpo. A tia do locutor seria o único parente que ainda visita, por causa da idade dela. Se um misto de autoimagem positiva e de precaução de crítica se acha em jogo, deve-se notar que a questão da velhice é um tema relevante. A contrajunção se ancora num entimema que, frente às conclusões "óbvias", não permite afirmar que a mulher esteja fraca, doente ou debilitada. É por não aplicar os traços “inerentes" à velhice à tia que o locutor usa o adversativo.

Eis o encadeamento que se estabelece por meio do operador contrajuntivo: pessoas que têm determinada idade apresentam problemas; a tia é uma pessoa que tem noventa e um anos e, portanto, está velha; o interlocutor sabe disso e pode ser levado à conclusão de que não está "firme"; ele deve ser levado a saber que ela está bem de saúde e contraria o senso em relação à velhice. $\mathrm{O}$ enunciado possui, pois, uma baliza que estabelece que os corpos devem se manter saudáveis, sob pena de rejeição por indícios pouco simpáticos.

Contrariamente a culturas em que a velhice significa sabedoria, na ocidental, por ser capitalista (não só, pois a religião assombra com o presságio da vida eterna), a velhice é descartável, por ser improdutiva e indiciar sofrimento. 
(E) Num jogo de vôlei do campeonato italiano, na ESPN, o comentarista proferiu o enunciado transcrito a seguir e que se referia à jogadora Simonetti:

(7) - Ela é a libero do time do Pésaro. Ela chega e toca em todas as bolas. Ela é baixinha, mas é muito enjoada, viu!!!

$\mathrm{O}$ enunciado permite perceber que a jogadora realizava acima do esperado a sua função, pois chegava e tocava em todas as bolas e era muito enjoada, inibindo a construção de pontuação satisfatória. Nada contra o desempenho, pois está fazendo o que é esperado.

Mas algo incomoda o narrador e o faz inferir que a atleta não poderia ter esse desempenho. O enunciado permite entrever que Simonetti não poderia ser líbero, não deveria chegar e tocar em todas as bolas e nem ser muito enjoada, pois era baixinha. A surpresa se refere à contradição observada entre o porte e o desempenho.

Considerando que enjoada tem o efeito de eficácia e isto se deve ao fato de ser uma boa líbero e por chegar e tocar em todas as bolas, o encadeamento da reflexão considera que jogadoras baixinhas não chegam e tocam em todas as bolas, dada a sua inferioridade física; que Simonetti é uma jogadora baixinha; e que não poderia ser enjoada e nem chegar a todas as bolas. Mas a atleta feria a regra aplicável ao seu caso, sem invalidar o lastro de crença geral.

Que uma estatura baixa possa gerar dificuldade para o menor, já que o que se confronta é a conformação física, até se poderia conceder, com ressalvas. Porém, à luz de comparações físicas, fazem-se derivas que imbricam altura e desempenho intelectual, o que não deveria ocorrer, pois, entre estatura e desenvoltura psicológica, não existe relação implicativa.

(F) O enunciado a seguir pertence a Sara Sarada, de Uma Escolinha Muito Louca, da Bandeirantes, apresentado por Sidney Magal. Ele foi coletado no dia $1^{\circ}$ de maio de 2009 , às $20^{\prime} 55$.

(8) - Pode perguntar, professor, porque eu sou loira, sou gorda, mas sou inteligente. 
Sara é uma pessoa cujo corpo se encaixa no padrão estético, com contornos delineados e aparência saudável, sem gostar de si mesma. A discussão gira em torno de a personagem possuir um corpo escultural, mas achar que está fora de forma. O humor do enunciado se deveu ao fato de se dizer gorda: este é o bordão. Que se dissesse gorda cumpriria os fins do quadro, sem precisar enunciar o restante. Mas, dizendo o que disse, abriu espaço para que efeitos de sentido circulassem. O problema é por que, entre ser loira e gorda e ser inteligente, há uma relação contraditória.

A relação entre as propriedades não tem um princípio racional, sendo a premissa geral falaciosa, pois pessoas loiras e gordas não são limitadas cognitivamente; nem mais nem menos do que as que têm outra cor de cabelo e um corpo que não seja gordo. O "defeito" deriva de um corpo que não se encaixa nos padrões da normalidade física pregada e, por isso, não seria desejável.

Sobre o silogismo se basear na obesidade, lembre-se que ela é associada a problemas indesejáveis. Por um lado, ela toma como referência o corpo de modelos que posam para revistas, desfilam ou são mostradas em novelas. Exceto atores consagrados que não precisam provar talento, a seleção de novos rostos e corpos parece se pautar num rosto bonito e num corpo de acordo com os padrões televisivos. Basta observar os rostos que ocupam espaços em novelas, programas de auditório ou filmes exibidos. Por outro, cria-se uma imbricação entre obesidade e morbidade: o corpo gordo é associado a um quadro propício para distúrbios cardiovasculares, ameaça desagradável.

Deve-se notar que loiro e gordo não são causa de insuficiência cognitiva. Por sobredeterminação, um problema físico sustenta a afirmação de disfunções psicológicas. Loiros ou gordos estão fora e são suspeitos. Que uma loira cative os olhares não parece pesar frente às relações que se fazem sobre a cor do cabelo e a suposta pouca intelectualidade. A resposta salvadora, talvez, seja a atribuição ao voyeurismo: denunciação do desejo.

(G) O diálogo a seguir acontece no filme $A$ Liberdade é Azul (Three Colors Blue) entre a síndica e Julie e incide sobre a moradora do prédio, que é prostituta. 
(9) - Vim pedir que assine aqui.

- O que é isso?

- Todos já assinaram. Não queremos mulheres que recebem homens aqui. A vizinha ...

- Lamento. Não me meto nisso.

- Mas é uma puta.

- Não é da minha conta.

Aqui, a contrajunção reitera a tese que comanda a "dedução", reportando-se ao caso que rompe com o "axioma" e fazendo decorrer a sanção prevista para o uso do corpo pela puta. Neste caso, a contrajunção apresenta o caso da vizinha, que, por ser prostituta, deve ser expulsa. Contra a recusa de Julie de assinar o manifesto de expulsão, o mas introduz o argumento para superar a reticência frente ao princípio que prostituta fica à margem da sociedade, já que é um mau exemplo.

$\mathrm{O}$ fato de os moradores assinarem o documento revela que a comunidade partilha uma grade de valores. Como se encontra frente à recusa, a síndica se vale do mas para provoca a adesão, justificar a aplicação do silogismo e negar a "omissão" de Julie. O mas encabeça a premissa contradiz a atitude da moradora que não concorda com os preceitos sociais sobre prostitutas.

O mote da discussão é a atividade da vizinha que faz um uso indigno do corpo. Não estão em jogo marcas visíveis do corpo. O tema se refere ao uso dele para uma destinação indigna. Que isto seja feito na periferia das cidades ou que prostitutas existam não é tematizado: trata-se de fazer com que não se misturem. Não se exige mais que os corpos sejam marcados a ferro para ostentar o estigma do "pecado": mas se produz uma segregação mais violenta do que carne marcada por metal em brasa.

Arma-se, pois, um palco que põe, de um lado, a crença de que as pessoas fazem escolhas, não cabendo julgá-las, e, de outro, a visão de que se deve aplicar a punição prevista a elas. Há dois imaginários em "diálogo" e cada um, dado o princípio de crença que o sustenta, é responsável por cadeias inferenciais distintas: um determina que a prostituta seja exilada; o outro, que viva a vida escolhida. Pontos de vista distintos, conclusões diferentes; princípios imaginários diferentes, atitudes concretas distintas. $\mathrm{E}$ 
o costume em comum vence, pois Julie é a única a não assinar o pedido de despejo e a não se submeter à norma.

(H) $\mathrm{O}$ enunciado a seguir foi proferido por um entrevistado sobre o tema da infidelidade. A entrevista foi feita numa casa de swing e foi ao ar no dia 5 de junho de 2009 , às $23^{\prime} 30$. Os casais se encontravam aos pares.

(10) - Esta é a nossa primeira vez. É um pouco estranho e a gente não está muito à vontade. Estamos um pouco nervosos e preocupados. Mas estamos gostando.

Defende-se que as sensações alegadas se devem ao fato ocupar um espaço impertinente, embora, mais do que estar num espaço inesperado, a pouca usualidade da situação instaure medos. Seja pela localização geográfica repreensível ou pela disposição para uma prática sexual ilegítima, anseios e temores são confessados, embora não sejam fortes para demover os curiosos. Eis duas experiências do corpo que são postas sob suspeita: a colocação em lugar indevido e a disposição para a prática sexual marginal.

Embora a primeira vez possa gerar os sentimentos mencionados, entende-se que é a experiência a que se refere que se incumbe de instaurar os ânimos descritos. Não é por ser iniciante, ou só por isso, que o calouro sente o que diz, mas por estar em confronto com a normalidade do mundo erótico. À luz de um imaginário que dita um modo de viver e de experimentar a sexualidade, as sensações são óbvias. Um palco inadequado e a disposição para viver uma sexualidade ilegítima não poderiam causar bem-estar.

Mas conta, em maior grau, o imaginário que fixa que corpos em locais suspeitos e em relações anormais se sintam estranhos e preocupados. Dada a previsão social, nada mais óbvio do que a afirmação de não estar gostando da experiência. Porém, contra a previsão social e a certeza de uma conclusão, o locutor afirma se sentir bem. Não faltam discursos que se pronunciam sobre o tema, seja moralista, jurídico, científico ou religioso, tecendo hipóteses sobre o desvio do "bom senso" e sobre a sedução por algo desviante como relações extraconjugais. Que a atitude seja imoral, pecaminosa, ilegal ou explicável a partir de uma visada teórica não evita 
que seja tida como desviante, pois vozes serem chamadas para abordar o que está acontecendo é sintoma de que o desvio está a caminho.

(I) $\mathrm{O}$ enunciado a seguir foi dito por um membro do grupo de apoio da irmã de Rachel, Kim, no filme O casamento de Rachel (Rachel Getting Married), quando falava sobre a sua adicção.

(11) - Eu não me achava adicta. Levei um ano para admitir que era. E durante anos eu era isso. Era uma adicta. É um fato que temos que aceitar, como tantos outros, mas posso ser isso e outras coisas.

O depoimento de Kim se refere ao fato de não admitir que é adicta e de não aceitar que a dependência seria incontornável e, por fim, de constatar que, apesar de ter que viver com o eterno controle sobre a doença, poder aceitá-la de modo submisso ou combatê-la, podendo, embora sendo adicta, não se submeter ao poderio da droga. $\mathrm{O}$ enunciado se baseia em três princípios que são correntes em relação à adicção: o dependente não reconhece a doença; depois, aceita-a e convive com o problema; e, às vezes, é conduzido à superação: eis os grupos de apoio.

Seja porque o consumo de tóxicos gera problemas; porque o adicto, em face de suas atitudes, é estigmatizado; ou porque ele associado a uma pessoa fraca e doente, um conjunto de prismas é criado, fazendo-o, pela pressão a que é submetido, agir para a ratificação da sua condição, ou para a busca da superação e da escolha de outro caminho. A expectativa das pessoas que têm relações com o adicto se dá no sentido da superação. É neste diapasão que a personagem organiza o seu sistema de referência.

Verifica-se uma crença impregnada de impotência que fixa que o homem pode aceder aos males de que padece, mas nada pode fazer sobre a dependência química. Mais poderosa do que ele, a droga não admite confronto. Frente a este quadro de aceitação passiva, a personagem se posiciona no sentido de afirmar que é possível se render ao inimigo ou buscar ser outras coisas.

Mas, contrariamente à posição determinista farmacológica (por que não psiquiátrica?), a personagem, por meio da contrajunção, afirma que, contra a aceitação da condição, buscará a ruptura por meio do grupo, sugerindo a legitimação dessa perspectiva de compreensão, assumindo um 
discurso favorável à existência dos grupos de autoajuda e levando o espectador a concordar com uma visada discursiva: frente à fatalidade mecânica, apresenta-se a defesa da solidariedade, do voluntarismo e do livre arbítrio.

O discurso de Kim, como contradiscurso à posição fatalista, é gerado por um prisma que desenha uma corporalidade indigna: o uso dela para consumo de drogas. Mais do que constituir uma ressalva sobre um princípio, uma voz é assumida contra a outra, o que é feito de forma restrita. Mais do que resguardar um caso particular, a contrajunção se faz ao sabor de uma injunção que ordena o mundo. São dois discursos, duas vozes, duas formações discursivas ou duas ideologias que digladiam, supondo uma mais esclarecida que a outra. No bojo de ambas, a contradição a um uso corporal, o que amplia ainda mais o leque das proibições sobre o que não deve constituir a corporalidade.

\section{ALGUMAS PONDERAÇÕES}

Seja porque traz sobre o corpo marcas inscritas que o tornam diferente, seja porque faz um uso corporal não sancionado pelo grupo, seja porque padece de males que o afastam do consenso, seja porque não pode ocupar um espaço, seja porque apresenta uma compleição física que excede o padrão, seja porque exibe mutilação, seja porque determinadas diferenças podem ser tidas como deficiência, o mundo da normalidade categoriza e define os limites entre os que podem e os que não podem ser deixados em paz, entre aqueles que têm que ser discriminados, porque não se encaixam no tipo dado como aceitável. Trata-se a cada momento de fixar as linhas que demarcam os corpos conformes e disformes, quer seja em termos de imagética física ou de expectativa comportamental.

Os episódios analisados revelam que há um discurso que se produz ao sabor da trivialidade, da efemeridade, da reiteração da ordem, da injunção de visadas e da reiteração de práticas, que, apesar de pouco memorizável, porque parece pouco importante, ratifica uma memória que apresenta pouca consistência racional, mas constitui a criação de um corpo indigno. Os enunciados trazidos para a discussão não têm compromisso 
com a tentativa, inglória, de arrebanhar tudo o que é o corpo indigno e não deveria trazer enquanto marca que o põe sob a suspeição da sociedade. Eles buscam, menos do que isso, indicar um lugar de observação e de possibilidade da efetiva aceitação da diferença, por meio do aprendizado da tolerância.

De acordo com Bourdieu (1999, p. 83), “o mal-estar, a timidez e a vergonha são tanto mais fortes quanto maior a desproporção entre o corpo socialmente exigido e a relação prática com o próprio corpo imposta pelos olhares e as relações dos outros". Considerando-se o que afirma o autor, poder-se-ia, enganosamente, ser levado a pensar que se pode estar numa das margens do rio: de um lado, aquela em que estão arrebanhados os anormais, cuja travessia depende da redenção que pode ou não acontecer, que é possível ou terá que ser vivida até o fim dos tempos; do outro, aquela em que se encontram reunidos os que atendem ao padrão estabelecido e podem ser deixados em paz e viver em silêncio benéfico e apaziguador: ao abrigo do mundo. Porém, percebe-se que a violência que se abate sobre os disformes também se aplica sobre os conformes, pairando como ameaça sobre a possibilidade de cada um deixar de pertencer à margem direita do rio, sendo conduzido para o outro lado e passando a ser um desvio que deve ser discriminado. A violência exercida sobre os diferentes não é distinta da que se abate sobre os iguais, embora o silêncio recompensador possa levar a pensar que se está imune às ofensas, porque se está no modo certo de ser. Por se fazer mais ruidosa sobre uns do que sobre outros, não significa que a força da injunção social deixe de atingir a todos, cobrando continuamente que os conformados continuem dentro do padrão e que os anormais se redimam e se enquadrem. Como afirma Foucault (1999, p. 25) 5 , “o corpo está mergulhado num campo político; as relações de poder [microfísicas] têm alcance imediato sobre ele; elas o investem, o marcam, o dirigem, o supliciam, sujeitam-no a trabalhos, obrigam-no a cerimônias, exigem-lhe sinais".

\footnotetext{
${ }^{5}$ A referência brevíssima a Foucault não deve levar a concluir que se esteja pretendendo adentrar ao campo epistemológico do autor ou se aproximar miradas teóricas "inconciliáveis". A referência ao autor é feita em virtude de vir dele um dos estudos mais sistemáticos sobre a corporalidade.
} 
Seja por "sugestão mimética", "injunções explícitas" (ou, sobretudo, implícitas, dever-se-ia acrescentar, dada a observação do funcionamento da contrajunção) ou "construção simbólica da visão do corpo biológico", produz-se um "habitus [...] diferenciado e diferenciador" (BOURDIEU, 1999, p. 70, grifo do autor), que fixa sistemas de referência a partir dos quais os corpos são julgados, sancionados e punidos, cabendo a cada um dos partícipes da comunidade a vigília e a observação, para que as transgressões sejam reconduzidas (se possível) ao bom senso. Que os transgressores tenham marcada a ferro em brasa sobre a omoplata a letra escarlate é uma prática que deixou de ser usada, mas isso não significa que o olhar que separa e isola o aceitável do inaceitável, o elogiável do repreensível, o digno do indigno deixe de imprimir estigmas sobre os que se desviam, ocorra isto por meio de gestos voluntários ou incontroláveis.

\section{REFERÊNCIAS}

BAKHTIN, M. Estética da criação verbal. Trad. Maria Ermantina Galvão Gomes Pereira. São Paulo: Martins Fontes, 1992.

BARTHES, R. Aula. Trad. Leyla Perrone-Moisés. 6.ed. São Paulo: Editora Cultrix, 1997.

BOURDIEU, P. A dominação masculina. Trad. Maria Helena Kühner. Rio de Janeiro: Bertrand Brasil, 1999.

CASTORIADIS, C. A instituição imaginária da sociedade. Trad. Guy Reynaud. 6.ed. Rio de Janeiro: Paz e Terra, 1982.

ECO, U. Lector in fabula. Trad. Attílio Cancian. São Paulo: Perspectiva, 1986. FOUCAULT, M. Vigiar e punir. Trad. Raquel Ramalhete. 19.ed. Petrópolis: Vozes, 1999.

MAINGUENEAU, D. Cenas da enunciação. Org. Sírio Possenti e Maria Cecília Pérez de Souza-e-Silva. São Paulo: Parábola Editorial, 2008.

PÊCHEUX, M. Semântica e discurso: uma crítica à afirmação do óbvio. Trad. Eni Pulcinelli Orlandi et al. 2. ed. Campinas, SP: Editora da Unicamp, 1995.

THOMPSON, E. P. Costumes em comum: estudos sobre a cultura popular tradicional. Trad. Rosaura Eichemberg. 2.ed. São Paulo: Companhia das Letras, 1998.

VANEIGEM, R. Nada é proibido, tudo pode ser dito: reflexões sobre a liberdade de expressão. São Paulo: Parábola Editorial, 2004. 


\section{Recebido em: 07/12/12. Aprovado em: 17/08/13.}

Title: Contrajunction and the body: the indignant and the amoral Author: João Carlos Cattelan

Abstract: This study is dedicated to the observation of ordinary discourse (a type of discourse present in the discursive order, in the reiteration of its practices, in the triviality, in the ephemerality, and in the injunction for the maintenance of the game) by taking a specific point of view: the analysis focuses on utterances constructed with contrajunctive connectives, in particular, the adversative "mas" (but). The aims are to elucidate what these connectives, by means of discursive transversality, reveal about the interdiscourse with the established imaginary; to retrieve what was previously said, produced before, elsewhere and independently, which perpendicularly crosses the discourse produced in the deictic axis of the here and now; and to access the supporters that guide the joints between parts of an utterance. In particular, this study aims at examining how contrajunctive statements oppose propositions when the topic refers to the physical embodiment of man.

Keywords: Ordinary Discourse. Transversality. Contrajunction. Embodiment.

Título: La contrajunción y el cuerpo: lo indigno y lo anormal Autor: João Carlos Cattelan

Resumen: Este estudio se dedica a la observación del discurso ordinario (un tipo de discurso que se pauta en el orden discursivo, en la reiteración de sus prácticas, en la trivialidad, en lo efimero y en el mandato al mantenimiento del juego), haciéndolo a partir de un punto de vista especifico: el foco de análisis incide sobre enunciados construidos con conectivos contrajuntivos, en especial con el mas adversativo, buscando elucidar lo que elles revelan, por medio de la transversalidad discursiva, sobre el interdiscurso que realizan con el imaginario establecido; rescatar el dicho anterior, producido antes, en otro lugar e independientemente, que atraviesa perpendicularmente el discurso producido en el eje deíctico del aquí $y$ ahora; y tener acceso a sustentáculos que comandan las articulaciones efectuadas entre las partes de un enunciado. En este trabajo, en especial, se buscará observar como enunciados contrajuntivos oponen partes de enunciado, en cuanto a temática se refiere a la corporalidad física del hombre.

Palabras-clave: Discurso Ordinario. Transversalidad.

Contrajunción. Corporalidad. 